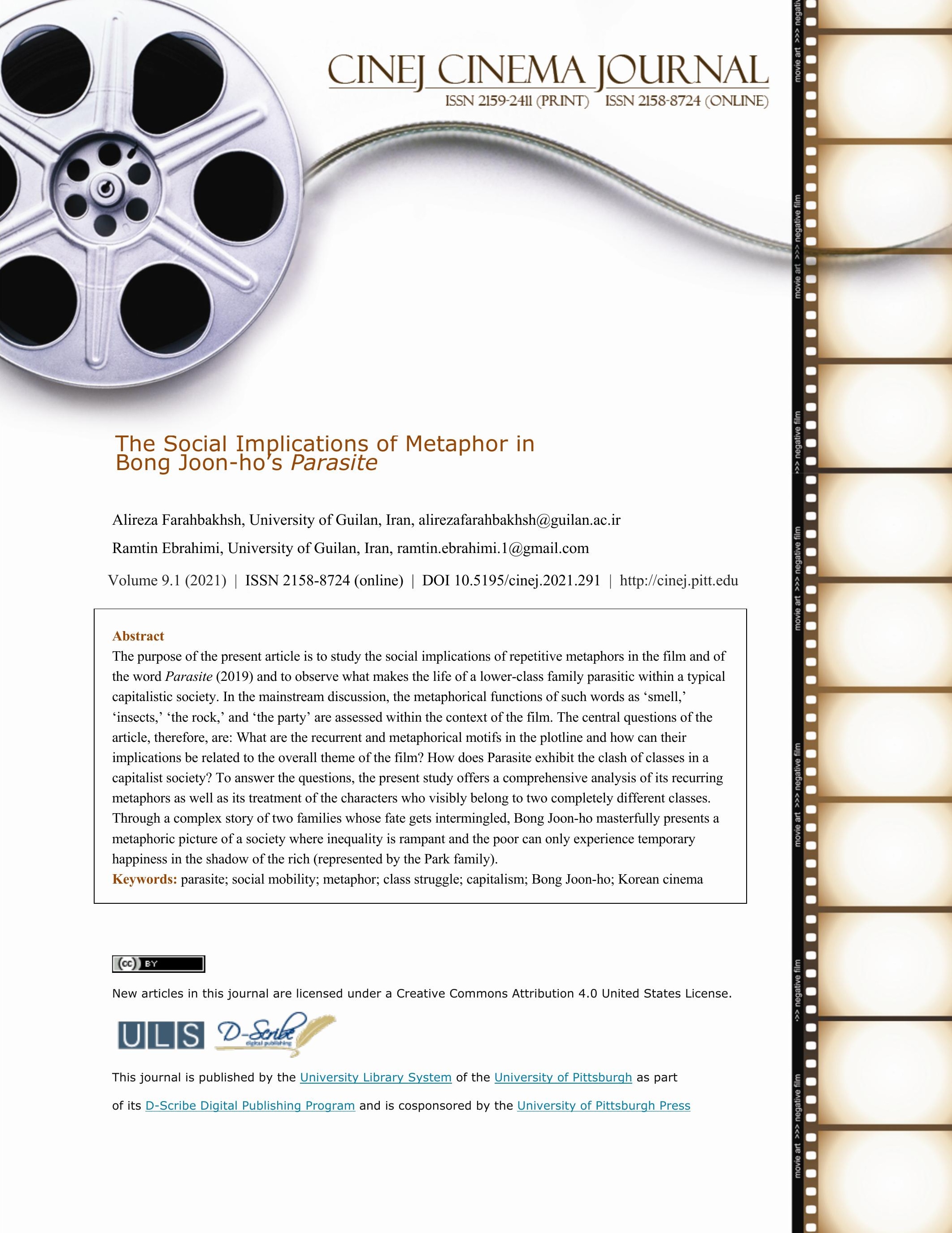




\section{The Social Implications of Metaphor in Bong Joon-ho's Parasite}

\section{Introduction}

In his essay "The Distribution of Power Within the Political Community: Class, Status, Party",

Max Weber argues that class identities form, and take shape, not from interactions and encounters

between the members of the same class, but from encounters with members from different classes

$(1978,930)$. One can take this predisposition further by analyzing how the members of a class, the

lower/working class, become aware of how they are different from the rich, and how inequalities

seem to show themselves in such situations. They do not become fully aware of class stratification

in the society until a moment in which two, or more, classes meet. The awareness of class

stratification is important in a capitalist society in which the change in the social class, although

promised, is essentially either impossible or unlikely for a large number of people. In Bong Joon-

ho's Parasite, the lives of the lower class and the upper middle class in a capitalist society are

intertwined in a world where the former always stands in the shadow of the latter, and only when

it is confronted with the reality of its current situation that the latter can see itself as what it really

is in the eyes of the wealthy - replaceable.

The word 'Class' in this context "designates a position in the economic structure of society"

(James 1999, 186) and it is rooted in the writings of Karl Marx. Writing about class stratification 
in capitalist societies, Marx argues that "insofar as millions of families live under conditions of existence that separate their mode of life, their interests, and their culture from those of the other classes, and put them in hostile opposition to the latter, they form a class" $(1972,106)$. Class representation and reflection of class conflicts in films can be traced back to the silent film era in movies such as Fritz Lang's Metropolis (1927) where, interestingly enough, the image of the working class as victims was subverted to show workers as "agents of their own destruction" (Turner 1999, 176). But the emergence of Marxist criticism in film studies, especially the study of class relations in the cinema, flourished during the 1960s both in Europe and in the United States. While French critics, especially those writing for Cahiers du cinema and Cinematheque, seem to have been the pioneers of applying such criticism to films (Kleinhans \& Lesage 1998, 147-148), their American counterparts began to offer Marxist readings of various films in the era of Blaxploitation and Sexploitation films (and the subsequent black and feminist movements) when class and gender became topics of interest. This attitude, however, has rarely been reflected in films as such, especially in Hollywood films. In the same vein, Keith Gandall has argued that the lower class has traditionally been represented in such a way that it seems the "come out of middleclass fantasies and serve those fantasies more than any other social aim" $(2007,6)$. Referring to this attitude, he uses the term "Classploitation" (ibid. 3). This idea turns around the proposition that the poor in fiction do not represent the reality but a version of reality seen through an 
ideological lens which has been exploited in Hollywood films. More recently, this ideological representation has been called into question in a growing number of movies that focus on the problems of the lower class, and the injustice that exists in (capitalistic) societies. In recent years, various movies have emphasized a bleak depiction of class relations and struggle in the world and, as it will be discussed in detail, Bong Joon-ho's Parasite seems to be the latest masterful account of the never-ending conflict between the lower class and the upper class in a capitalist society.

As one of the finest South Korean filmmakers, Bong Joon-ho had already expressed his concerns about life in a capitalist society in his critically acclaimed film Snowpiercer (2013). The film depicts a world in which the earth has turned into a freezing place where no one can survive the harsh climate, except those boarded on a protected train which circles round the world. People in the train are divided into different sections, the so called 'tail' and 'head' sections, and each wagon leading to the head includes sections and people who are of more use to the rich, and the protagonists, who belong to the lower class, live in the last wagons reserved for the workers. Unable to tolerate the harsh living conditions in the tail section and willing to do anything to rise against the tyranny, they hatch a plan to go from the tail (the lower class) to the head (the higher class) to defeat the dictator(s) in charge of the train. Although the apocalyptic message of Snowpiercer is visibly different from that of Parasite, in it, references to capitalism and the 
destruction and injustice the system had brought to the world are found everywhere. A radical political idea runs behind Snowpiercer, as it "connects political economy to political ecology" where the problems people have to put up with can be traced back to the capitalist domination in the world (Lee \& Manicastri 2018, 3).

Bong Joon-ho followed Snowpiercer with yet another socially and politically oriented film, namely, Okja (2017), in which he tells the story of inhumane treatment of animals for the sake of profit, and he offers his own understanding, and critique, of capitalist societies (and also problems created by human beings such as global warming) by focusing on a genetically-modified pig named Okja. As Josh Schulze postulates, Okja pictures "the varying degrees of social mobility in a modern industrial setting, and the relationship between manual labour and the disembodied corporate activity" (2018). Bong Joon-ho seems to "meditate on his home country's complex correspondence with globalisation as an impending development" and focuses on "the comparative locality of South Korea in conjunction with the pervasiveness of a global corporate entity" (ibid.). Therefore, it is evident that he had already expressed his concerns for the future of South Korea, and the world in a larger scale, in his earlier films. One can even trace these concerns to The Host (2006) in which careless behavior of scientists, their complete disregard for the nature and for people's lives, leads to the emergence of an atomic lizard that comes back years later to destroy 
the city. Parasite seems to be Bong Joon-ho's latest study of similar themes, but this time it is more metaphorical and structurally more complex.

This article seeks to analyze Bong Joon-ho's Parasite and its use of metaphor in an attempt to examine its underlying political and social themes, and observe its take on capitalism and the subsequent social stratification in South Korea and, in a bigger picture, the world. The study is significant in the sense that Bong Joon-ho seems to have built a metaphoric replica of Korean society in which each class plays its defined role in maintaining the capitalist system, and reflects the illusion of progress promised to the lower class. It seems that in recent years an increasing number of films have focused on class struggle in contemporary capitalist societies (such as The Platform (2019) and Atlantics (2019) among many), and Boon Joon-ho's film works as an excellent example of such attempts. The central questions of the article, therefore, are: What are the recurrent and metaphorical motifs in the plotline and how can their implications be related to the overall theme of the film? How does Parasite exhibit the clash of classes in a capitalist society? To answer these questions, the present study offers a comprehensive analysis of the film, and focuses on its uses of metaphor and metaphorical details as well as its treatment of the characters from two completely different worlds/classes. In the following pages, first a short summary of the film is supplied. The synopsis is followed by a study of the themes and major characters of the 
film to observe how the main characters are "personifications of economic relations' (Marx 1976,

178-179) and economic categories, and to see how people on the wrong side of class struggle are

likened to parasites and how in the process they begin to realize where they stand. The following section offers an analysis of the recurring metaphors including smell, insect, the scholar's rock, rain and the party, and their functions in the film. In the last section, the final confrontation of the classes and the climax of the film are examined.

\section{Discussion}

Parasite (2019) is Bong Joon-ho's seventh film; it won several prestigious awards including the Palme d'Or at the $72^{\text {nd }}$ Cannes Film Festival. The film revolves around a family of four, the Kims, living in a poor neighborhood in Seoul, South Korea. They live in a basement-like house which has a ground-level view of a narrow street. The four members of the family are unemployed; they are constantly on a lookout for a job and they even start folding pizza boxes for a pizza shop. The son's (Kim-woo's) old friend visits him one night and informs him that there is a girl who comes from a wealthy family, the Parks, for whom he works as an English tutor, but he is leaving Korea to study abroad and offers Kim-woo his own job as a tutor for the girl. Kim-woo asks his sister, the talented graphic artist Ki-jung, to forge a university certificate for him which proves that he is a student at the prestigious Seoul University. He soon begins his job as a tutor at Parks' house. The 
Park family includes the father, Dong-ik, who works for an IT company, the mother, Yeon-kyo, who is a housewife, the daughter, Da-hye, a fifteen year old teenager, and the son, Da-song. Once in the house, Kim-woo finds an opportunity to bring his sister to the house as a therapist who treats people with trauma or emotional issues to work with the son of family. Gradually, they hatch plans to bring their mother and father in the house as a housemaid and a driver respectively, as they force the previous housemaid out of the house. They, more or less, take over the house but soon realize that the husband of the previous housemaid lives in a hidden basement in the house and it triggers tension and conflict among the Kims, the housemaid, her husband, and, ultimately, the Parks as everything descends into violence and chaos.

In their analysis of Joon-ho's Snowpiercer, Lee and Manicastri (2018) write that the film reinforces the idea that "there is no alternative to the existing order" in this capitalist world (15). Parasite seems to be a tamer, yet more realistic, version in which social class, and the order that is believed to exist in a capitalist society, cannot be changed in a normal course of events, and any change, precipitated only by fraud and deception, is simply a pseudo-alternative because at the end, the poor are still creeping in the shadow of the rich, and even though the Kims seem to have temporarily replaced the owners of the house, they are soon kicked back to where they belong as underdogs. 
The film is divided into three separate acts, which are significantly different from one another. The first act introduces the life of the Kim \& Park families, creates a comic atmosphere, and brilliantly shows the differences between the classes in its treatment of these two families and their daily lives. The second act begins when the Kims have already disguised themselves as employees for the Park family. The Parks go on a birthday camping trip, the Kims celebrate in their house and the previous housemaid rings the doorbell. This is the beginning of the major conflict; gradually, the tone of the film becomes serious and the film turns into a drama. The third act, which is the shortest one, begins with a party scene incorporating the climax, and resolution, of the film where the characters go through a change, especially Ki-taek, the father of the Kim family, who finally becomes 'class-conscious,' in a sense, and takes matters in his own hands.

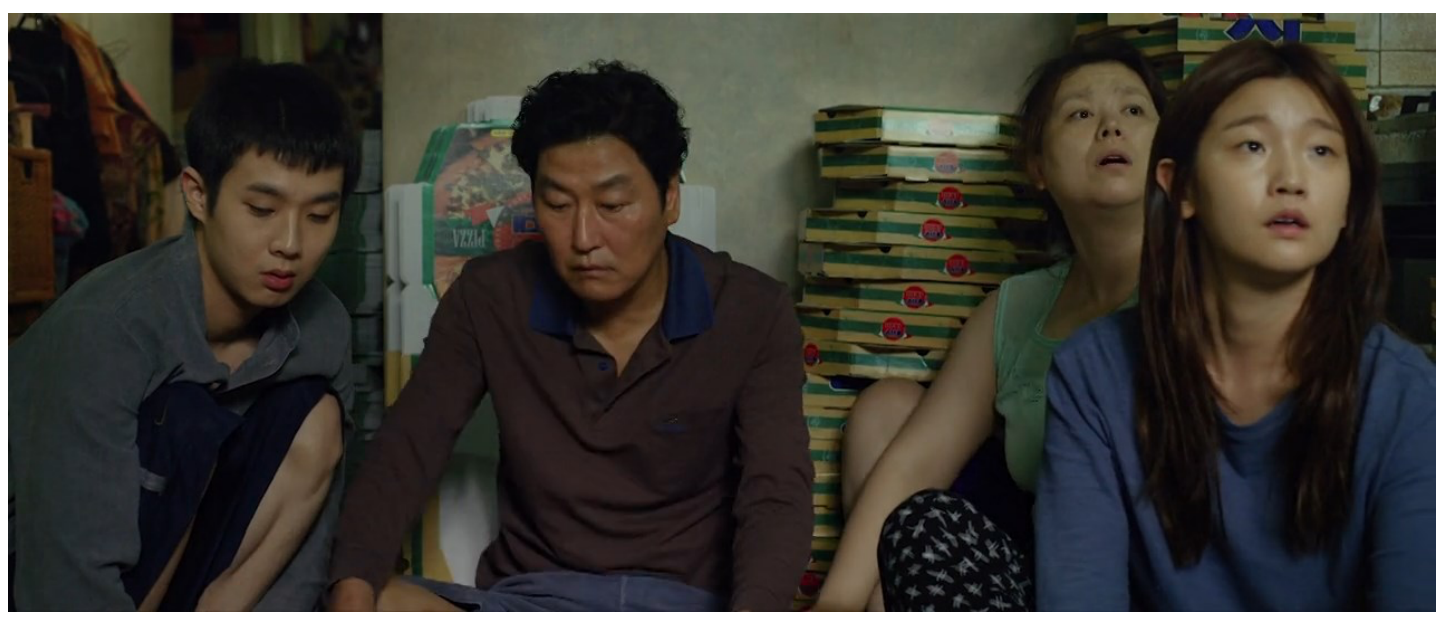

Figure 1. The Kims: poor, unemployed and desperate 
The Kims live underground, in a semi-basement house. They leech off a neighbor's Wi-Fi, hold temporary jobs such as folding pizza boxes, and live with bare minimums, but they are all intelligent and talented, specifically the children. Although Ki-woo (the son, later known as Kevin) does not have a university degree, he speaks English and knows how to teach. Ki-jung (the daughter, later known as Jessica) is a great graphic artist. She also can forge all kinds of documents, and as it becomes clear later, she is a quick learner and a potential therapist. On the other hand, the Parks lead a completely different life: they live in a luxurious mansion with a housemaid. The mother of the family is extremely superstitious, and Mr. Park, who is apparently famous in his field of expertise, seems to be mostly involved with his job. The differences between the families are too obvious to mention; yet, one interesting aspect of the Parks' house is when Ki-woo (or Kevin) first visits their mansion, we see beautiful bright shots of the house, with an intention of underscoring clear contrasts with the Kims' house. While the former is on the hills as the sun shines on the house and its front yard, the latter is a basement house where one never sees the sky. In fact, we never see a bright shot of their house or neighborhood, and their house resembles the hidden basement in the Parks' house which will be shown later in the film. The Kims live in the underground of Seoul, under the shadow of capitalism, and they are eternally doomed to be the underdogs, struggling for subsistence. 


\section{Smelly Insects}

There is an important scene in the second act of the film in which the Kims (the father, the daughter and the son) are hiding underneath the table in the living room while the Parks lie on the couch and have an intimate moment. This scene is one of the turning points of the film, and a significant moment of revelation for Ki-taek, as the head of the Kim family. As Richard Scase explains, in capitalist societies, there is a tendency for members of the lower class to view economic inequality as a problem of opportunity and not a social phenomenon which comes about as a result of capitalism (1992, 50-51), and the Kims thought that by changing their occupation (here disguising as drivers, tutors, and housemaids), they can take a step toward becoming 'owners' themselves, but in this moment, under the table, Ki-taek gradually realizes what he (or his family, or the whole lower class) is to the rich. For the father, the first moment of revelation is when they talk about the underwear which the girl, Ki-taek's daughter, had left in the car, thereby, unintentionally shaming the father who is underneath the table beside her son and daughter, and the second point is when Mr. Park states that his driver, Ki-taek, has a distinctive unpleasant smell, and that it annoys him. Here, the unpleasant smell distinguishes the lower class from the elite. The poor always smell, no matter how hard they try to hide themselves under the disguise of good clothes or colognes. They are easily detected by the rich, or so it seems by Mr. Park. The father has now become aware of not only their own social class, but also the fact that they are easily replaceable and made 
redundant. The idea of the replaceability of the lower class was emphasized earlier in the film when the previous housemaid and driver were fired with no good excuse. Ki-taek, who hears Mr. Park talk about his smell not being repugnant enough to cost him his job, is now a different man. Although Ki-taek (and the family, on a larger scale) has always been aware of their social status, he can now see more visibly where he stands in the society. As mentioned earlier, it is only through relation with the members of different classes that class identities are constructed. He is nothing but a servant and is doomed to remain one for the rest of his life. Now he understands that to the rich, they are like insects - like parasites.

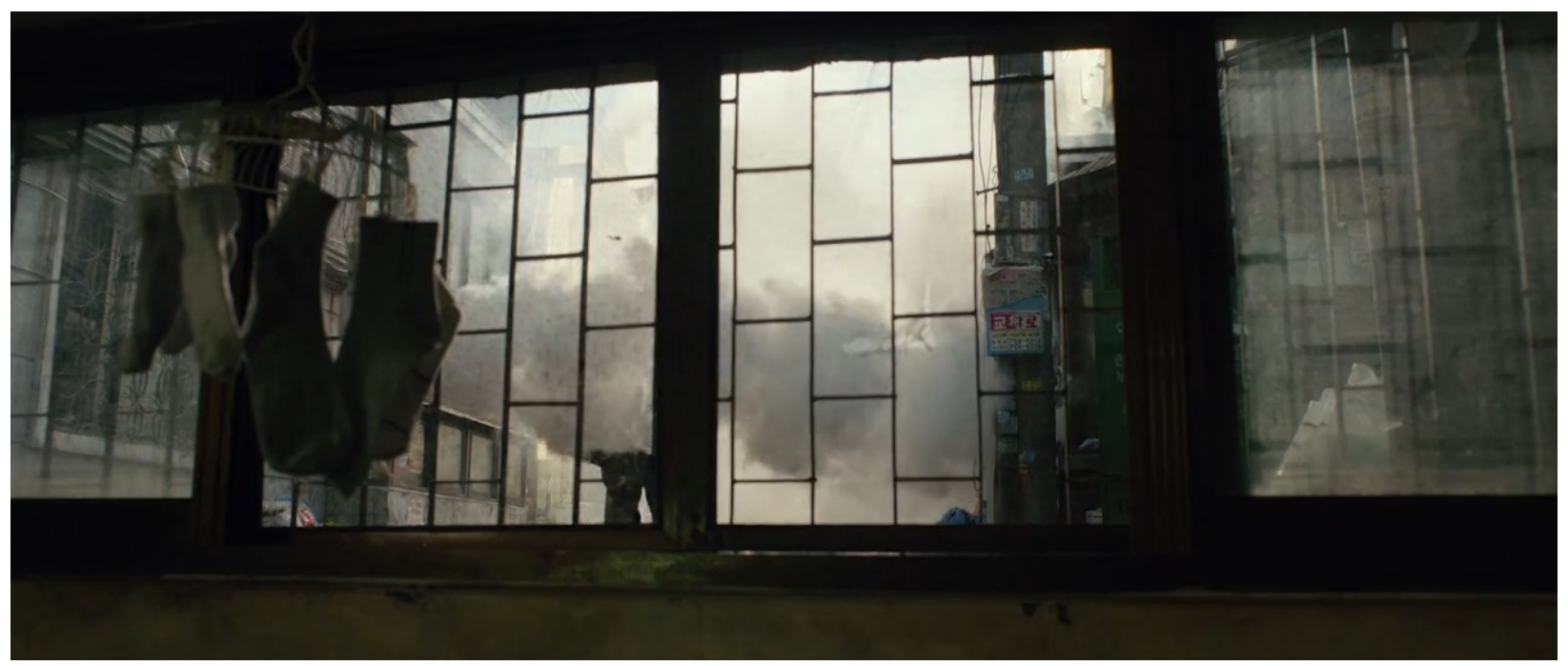

Figure 2. The Kims being wiped out like insects

The analogy between the Kims and parasites (or insects for that matter) can be found in numerous scenes: early in the movie, we see that the Kims are worried because the government is 
spraying anti-fumigation in the neighborhood. They try to close the windows of their basement house so they would not be affected, but much to their chagrin the spray fills their small house. The implication is that they are being wiped out like insects. A similar portrayal of the Kim family as insects can be found in the scene (mentioned earlier), where they hide underneath a table. They crawl under the table, and the father crawls out on the floor like a clumsy insect. These images, and the fact that they can only become themselves in the shadow of the rich, or through hiding their true identity during the day, seem to underline the idea that the Kim family is depicted, and treated as, parasites and insects. But who sees them as parasites? Is it the perspective of the upper class that is being forced on the audience? Can one say that the Kim family is doing what they are doing simply because they are desperate, because they are tired of being underdogs? In his official statement for Cannes Film Festival, Bong Joon-ho contends that it is increasingly the case in this sad world that humane relationships based on co-existence or symbiosis cannot hold, and one group is pushed into a parasitic relationship with another. In the midst of such a world, who can point their finger at a struggling family, locked in a fight for survival, and call them parasites? It's not that they were parasites from the start. They are our neighbors, friends, and colleagues, who have merely been pushed to the edge of a precipice. As a depiction of ordinary people who fall into an unavoidable commotion, this film is: A comedy without clowns, a tragedy without villains, 
all leading to a violent tangle and a headlong plunge down the stairs. (Parasite: International Press Kit 2019, 6)

The title of the film, Parasite, refers to the Kim family, and seems to be a clear reference to the way the upper class looks at the lower class, or rather how it seems in the society; the poor, in such a mindset, are depicted as smelly, off-putting, and repulsive. As mentioned earlier, we see such an attitude in other scenes, too, including the one in which they are in the car and Mr. Park is holding his coffee cup as to test how Ki-taek drives the car, and he is ready to fire him if he spills his coffee. The Kims are deemed to be replaceable and disposable, and the rich seem to have almost no mercy for their employees and no sense of responsibility (like the housemaid who is fired). In the scene where Mr. Park and his wife are on the couch while Ki-taek and his son and daughter are hiding under the table, Dong-ik explains why he has not fired Ki-taek: "Anyway, even though he always seems about to cross the line, he never does cross it. That's good"' (Parasite 01:27:4601:27:55). He wants a clear line between himself, the rich, and Ki-taek, the poor, so that the two are easily distinguished from one another.

In a wider scope, the Parks can also be considered as parasites in the sense that in a capitalistic society, the rich do nothing while the members of the lower class have to do all the dirty work. The director himself has emphasized the double meaning of the title: "you can say that rich family, 
they're also parasites in terms of labor. They can't even wash dishes, they can't drive themselves, so they leech off the poor family's labor" (Bong Joon-ho quoted in Ankers 2020). Therefore, the rich are parasites in that they wallow in wealth, have high-ranking jobs, and lead a life of luxury and comfort, while members of the lower class, who might be, and sometimes are, more intelligent, have to struggle for their basic needs.

There is a brief role-change in the film, which plainly reflects what goes on in South Korea (and presumably in all capitalist societies); the Kims seemingly change their social status from the destitute to the affluent, but this is made possible only when they are in disguise, and even then, it is not much of a change in itself anyway. In the final moments of the first act, the Kims are alone in the Parks' house, and they are eating, drinking, and having fun while the Parks are away on a vacation. They start talking about getting rich and living in the house as its owners:

Ki-woo (Kevin): If we lived here, which room would you want? What room in this masterwork by the great Namgoong?

Ki-jung (Jessica): I don't know. Get me the house first, then I'll think about it.

Ki-taek: We live here now, don't we? Getting drunk in the living room.

Ki-woo (Kevin): Right, we live here. Why not?

Ki-taek: This is our home right now. It's cosy. (Parasite 01:01:05-01:01:35) 


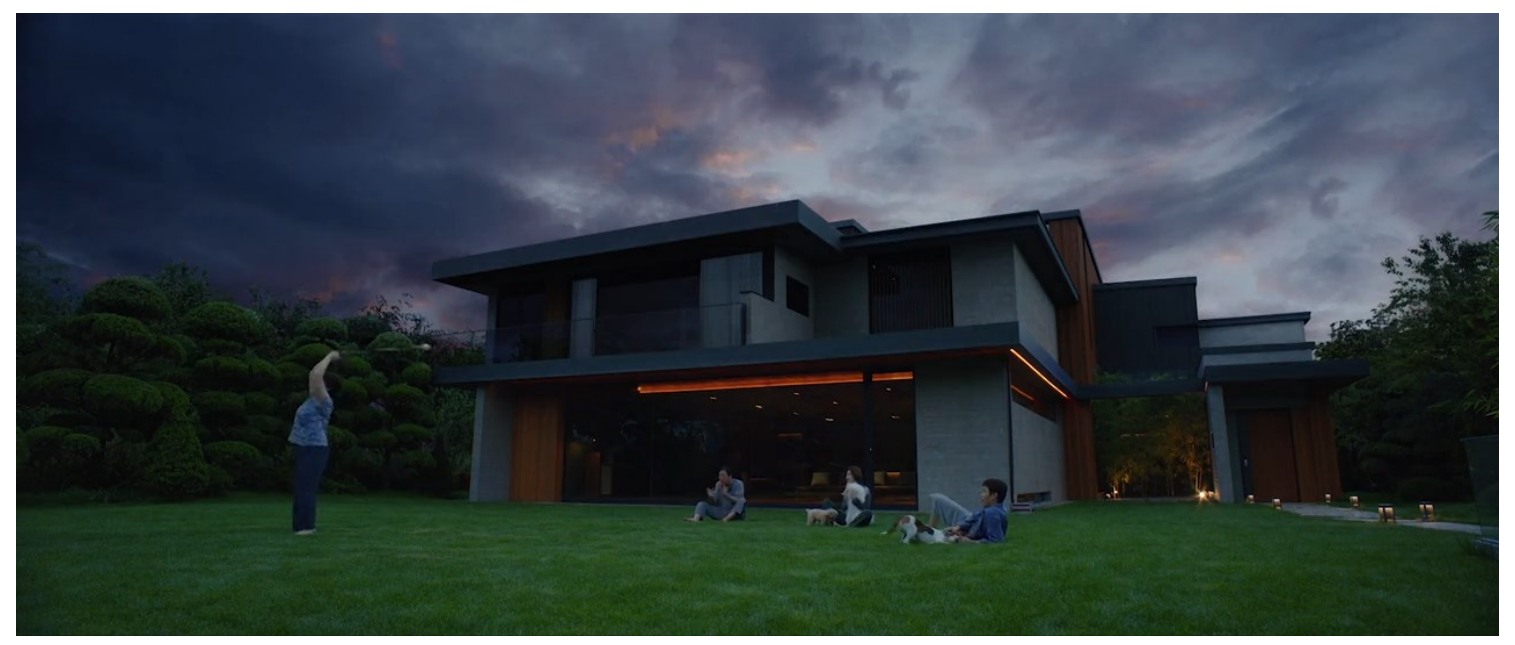

Figure 4. The Kims temporarily own the house in the absence of the Parks

They already think that they somehow own the house, this is their moment of happiness, and things

will be the same forever. But soon it will be clear that it is only temporary, they will never be the 'owners' themselves, and they will only live in the shadow of the rich. It seems as if Bong Joonho wanted the audience to understand the underlying structure of any given society. In other words, social mobility is not possible in the normal state of things. Of course, the son has dreams of studying and becoming rich, which in contemporary capitalism is promised if the person holds a degree and gradually finds jobs that lead to a better life, but the film implies that it will never happen, and the rich remain rich, while the poor continue to be poor.

One important aspect of the quoted conversation is in what follows; when the Kims are confronted by the previous housemaid and as they try to understand what is going on, the audience guesses that the family will soon overtake the rich, but this does not happen. The film shifts its 
tone from comic to drama, and introduces a new twist to the story. With the story of the previous housemaid and her husband who lives, and is stuck, in the basement, a new complication sets in. These two families, the Kims and the housemaid and her husband, soon fight with one another, because only one can stay in the dark corners of the house, and neither family wants their secret to be revealed. Socially and politically speaking, this confrontation proves significant. Together, they can rise against the rich (the elite) and (ideally) take over the house one way or another, or at least there is the possibility that it can happen in the society (as it has in human history), but instead, they fight over a small basement in a big house. They are confined within their small limited world and cannot see the truth, nor can they see what their current situation is. While the rich is not present, the members of the working class fight with one another for survival as underdogs. This, in turn, reflects what goes on among the lowly and the poor within a capitalist society. While they can co-exist and help one another to possibly overcome the barrier between themselves and the rich, they fight over, and are distracted by, a small space. Not only do they remain in the same lower class, but their lives get worse and worse. It is interesting to note that the housekeeper's husband, who is running away from loan sharks, is hiding in the basement of the Parks' house, and it seems that the poorer a person is, the lower in the ground he or she dwells (Thessaly La Force 2019). The Kims already lived in a semi-basement house, but as the plot unfolds, they descend into even more misery. 
While the screenplay is carefully structured and it involves a complex set of details, one disappointing aspect of the film seems to be the fact that the Parks are gullible. They are comically naïve and slow-witted, and they are easily manipulated throughout the film, first by the previous housemaid and her husband, and then by the Kims. This is evident, especially, in the mother, who always has silly thoughts about her son or the housemaid; she is easily fooled by plans hatched by the Kims in their joint conspiracy to control the members of the household. This simplicity in the Park family is even mentioned early in the film when Ki-woo's friend, who is offering him his job as a tutor for the family, describes the mother by saying that "How should I describe the mother...? She's a bit simple. Young and simple" (Parasite 10:33-10:42). But why is that? It seems that all members of the Park family are always manipulated, while the Kims are extremely clever, especially the daughter and the son. We see examples of their shrewdness not only in their plans to take over the house, but also in earlier scenes including those which show their success in deceiving the girl who co-owns the pizza shop to offer the son a job interview, or the daughter's skills in forging documents using Photoshop, or the son's ability to teach English even though he does not hold a university degree. This contrast between the Kims and the Parks establishes the comic mood of the first half of the movie and also functions as a metaphor for what happens in the society. While those underprivileged yet smart members of the lower class cannot afford to go to 
art schools or universities, and cannot find a proper job because of the certificates and qualifications they lack or the opportunities they have consequently missed, the rich who are, or it is better to say could be, inferior in the intellect are in effect the employers. They give orders and they complain, even though they are visibly not superior in anything. This is a terrible blow to the plausibility of the plot (as is the ridiculous coincidence at the end of the movie in which the son sees the Morse light beams sent by his father and discovers his secret hideout); are the rich really so stupid and dumb in the real word? Are they really so gullible and naïve? Nevertheless, this mistake may offer a vivid picture of the Korean society, and on a larger scale, of the capitalist world, where the privileged few have the chance of getting richer and more powerful, while the life of the poor floats away in the drain water.

There is a scene which comically sums up the differences between these two worlds: just before they return home because their birthday picnic was ruined by the rain, they call their housemaid to tell her to cook 'Rom-Don'. It is an invented word which Bong Joon-ho and the translator of the subtitle came up with; the actual name of the ramen dish is Chapaguri/Jjapaguri, which is a mixture of two inexpensive instant noodles. What makes this special dish absurd is that the Parks demand the housemaid to put highly expensive Korean Hanwoo beef in an otherwise inexpensive broth. The dish is a pretentious misuse of an expensive ingredient in a cheap noodle soup, where it does not belong, just like the Park family, or similar wealthy families, who actually 
do not belong to a society that is predominantly composed of middle and low class people. The opposite also applies: do the Kims (or metaphorically speaking, the smelly insects) belong to the capitalistic society, or even to the world?

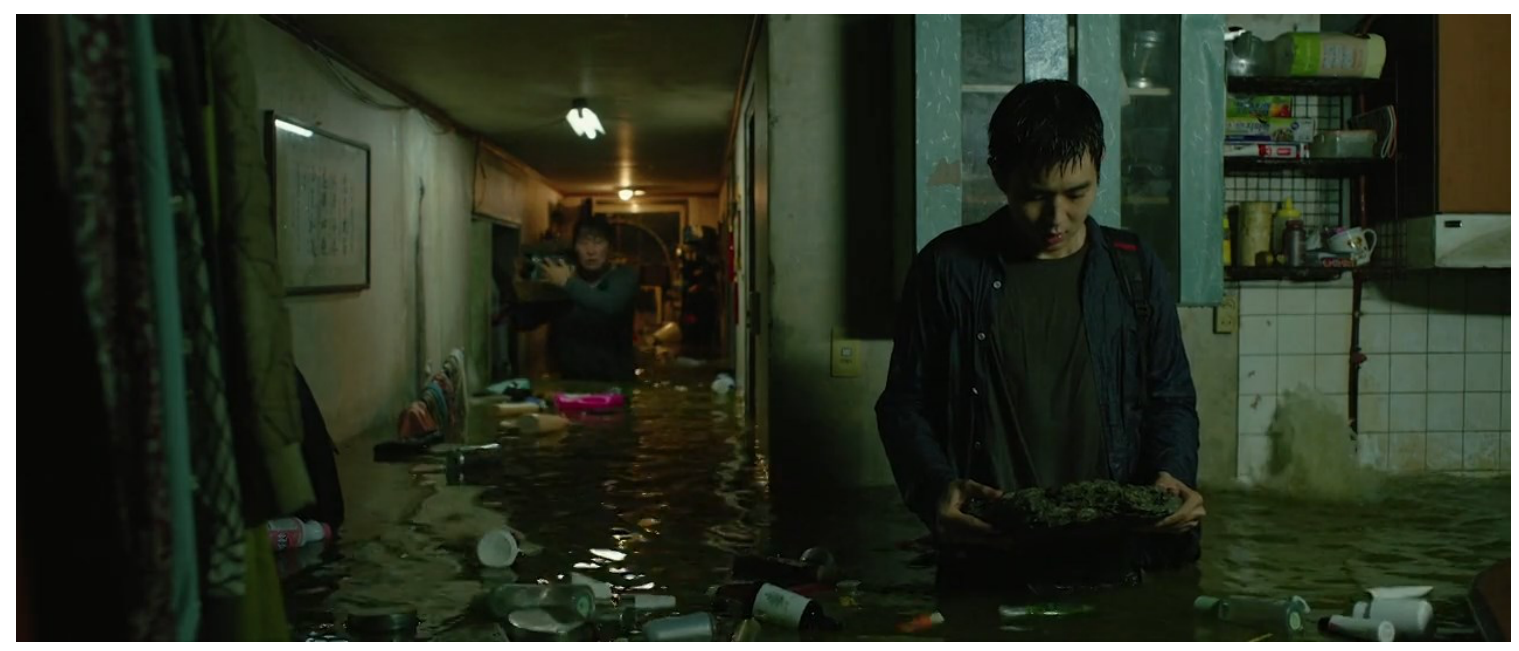

Figure 4. The rain drowns the poor

\section{The Scholar's Rock and the Rain}

While the film works as an extended metaphor for the Korean capitalist society, there are several objects or places in the film which signify the class stratification as represented in the story, and the symbols used in the film seem to reinforce the underlying metaphor and highlight the overall theme of the movie.

The scholar's rock which is a gift from Ki-woo's friend is a traditional ornamental rock that, according to his friend, brings "material wealth to families" (Parasite 07:45-07:48). In other words, it supposedly brings 'fortune' to the family, something which Chung-sook, the mother, 
cannot grasp because for her, fortune is abstract, and she mumbles that "food would be better" (Parasite 08:02-08:05). However, the father embraces the idea and likes the rock because he wants the family to prosper and make progress, and Ki-woo holds it in the air and describes it as something "so metaphysical" (Parasite 07:50-07:53). The role of the rock is ironic within the narrative structure of the film; on the one hand, it helps the family by being a blessing, giving them an opportunity to enter the Parks' house, but on the other, it is used as a tool for the housemaid's husband to hit Ki-woo on the head. The director Bong Joon-ho described the meaning of the rock by saying that "at the beginning, it's supposedly metaphorical, and then by the end, it's a literal weapon used to smash in somebody's head" (2019).

What is the metaphoric meaning of the rock? If one focuses on the scene in which the Kims' basement house floods, one can see the rock floating in water. Also, later in the film when the housemaid's husband uses it as a weapon to hit Ki-woo with, it does not kill him. It appears that the rock is hollow, and extremely lighter than a normal rock. The shallow scholar's rock seems to be a symbol for empty promises of social mobility in a capitalist society. It is a traditional symbol and it is supposed to bring fortune, but in reality, it is empty, and does not do anything. In fact, ironically, it does the opposite of what it is meant to do. Just like the opportunity to work at Parks' house, which turns out to be the opposite of what the Kim family had thought it would be, the rock does not lead to prosperity or social mobility, but to death and misery. The rock is like a façade, 
just like the dreams of becoming the owners of the house which the Kims, especially the Ki-taek, hoped to come true. Therefore, the rock is the symbolic manifestation of the lower class's failed hopes of becoming a part of the upper class, and, as mentioned, it represents how these promises of social mobility in a capitalist society are evidently empty and illusory.

In the second act of the film, which begins with the arrival of the previous housemaid, the rain functions as a significant political/social metaphor. What follows constitute an important turning point in the narrative. For the rich, rain is nothing to fret over; it can be something enjoyable, like the son's camping in the yard while the parents have an intimate moment on the sofa. Even later in the film, when Choi Yeon-gyo, the mother in the Park family, is on the phone, she emphatically exclaims: "that rain was such a blessing!" (Parasite 01:44:42-01:44:46). But things are different for the Kims and the lower class. When Ki-taek and her son and daughter leave the Park's property, it is pouring rain outside. The camera zooms on the sewers, signifying the move from the top to the absolute lowest, and then we see the Kims descending into their semibasement house. It is a series of shots in which they go down flights of stairs and get drenched. When they get to their neighborhood, both we and the Kims realize that the rain and the overflowing of sewage have destroyed their semi-basement house; the poor are being literally drowned and their house is ruined with sewage water, as a mixture of urine and feces pours all 
over them. Let us take a look at what each of them tries to salvage in the flood: Ki-taek picks up medals won by his son/daughter, which are the only signs of honor and progress in their family. Ki-woo (Kevin) picks up the scholar's rock as it is the only thing that can offer any glimpse of hope because it signified fortune, and $\mathrm{Ki}$-jung (or Jessica) simply gives up, as she sits on the overflowed toilet seat and smokes a cigarette; it appears that to her, things are beyond repair. We see an eye-level shot of their semi-basement house filled with sewage water. It is similar to the shot of Ki-taek shown in the same scene. It seems like he is looking at the disaster, at their life which is washed away in the rain. Everything falls apart right before their eyes. Almost the opposite happens in the Park family. The only inconvenience it brings for them is the cancellation of their camping trip, which is easily put behind by the yard camping and a romantic moment. Their house remains intact, while the life of the lower class falls into pieces.

After the rain, when the government puts them in a gym and they plan to go back to work, the smile in Ki-taek's face has disappeared. He has become fully aware of the hole they are stuck in. He knows there is no way out for them, and that their life can only get worse, and it does get worse. He despises the Park family and cannot hide this resentment. Almost the same reaction can be seen in his children, especially Ki-woo, the son. He had thought that it is possible for him to be a part of the Park family by marrying their daughter once she goes to college, but now he begins to actually see the gap between the classes. The catastrophic birthday party is underway and he 
looks at the guests and asks Da-hye (the daughter of the Park family): "In this setting, do I fit?" (Parasite 01:46:13-01:46:16). She obviously does not understand him because she has no idea about the life of the lower class. The younger generations of the upper class are just as blind to the world around them as their parents are, and they see the same 'lines' between them and the poor, and notice the same smell coming off of the poor. Earlier in the film, we had seen Da-song, the son of the Park family, sniffing both Ki-taek and his wife and saying "It's the same! They smell the same" (Parasite 51:45-51:48), later repeating that "Jessica smells like that, too" (Parasite 51:53-51:56). The implication is that even the next generation feels this gap, and notices this distinct smell/inferiority in the lower class.

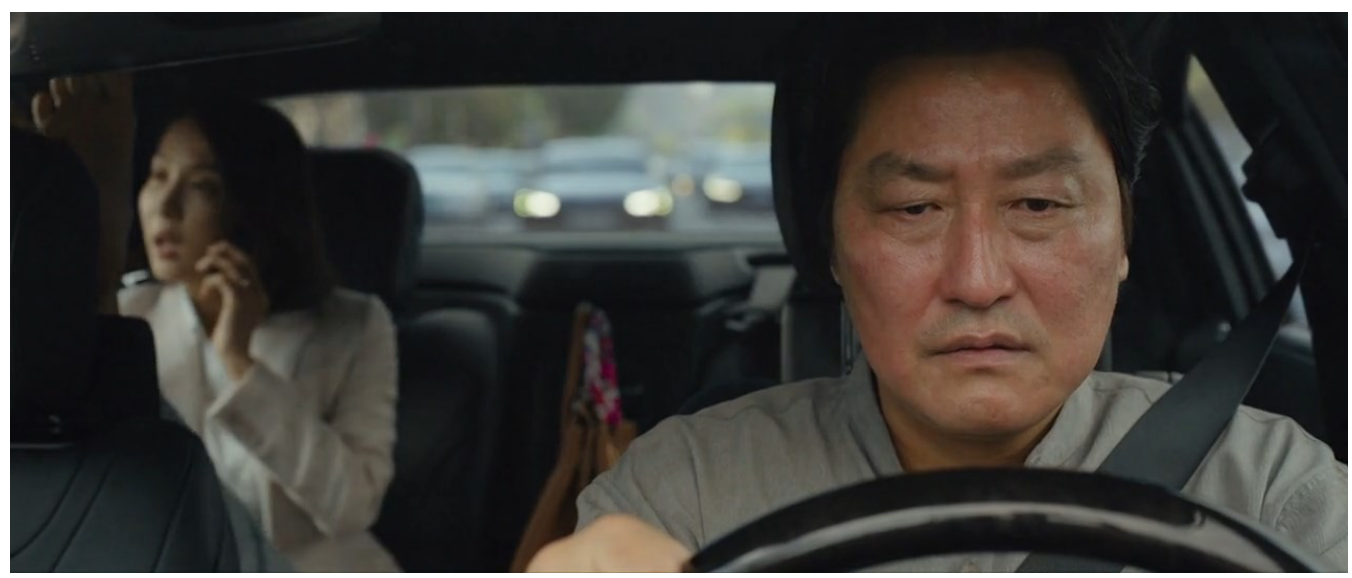

Figure 5. Preparation for the climax

The Party 
The party is the climax of the film where Ki-taek's explodes with anger. Geun-sae, the man in the basement, hits Ki-woo (Kevin) with the scholar's rock, picks up a knife, and runs to the party and stabs Ki-jung (Jessica), while Da-song, the son in the Park family, faints as he is confronted by Geun-sae (We know from earlier scenes that he was actually haunted by Geun-sae's eyes in the dark). The whole scene is now shown in slow-motion where Mr. Park rushes to get his son to the hospital, and he does not care about Jessica being stabbed or the confrontation in the yard; he only cares about himself and his family. Soon, the rich run for their lives and Ki-taek and Geun-sae are the only people left on the scene. Metaphorically speaking, the lower class is fighting with itself while the rich runs to safety. This is the last straw for Ki-taek. He was gradually becoming classconscious since the second act, and he cannot take it any longer. He sees his daughter, stabbed and nearly killed, his wife in a fight with the Geun-sae, and his son passed out with a bloody face. Mr. Park keeps shouting: "Get the car! Mr. Kim, what are you doing?" (Parasite 01:53:53-01:53:55). He does not care about them - not a bit. Mr. Park goes to get the car keys himself, and yet again he is disgusted with that 'smell' of the lower class; this time it is worse than before. In a moment of rage, Ki-taek kills Mr. Park and runs away while the others, including his wife and his stabbed daughter are frozen with shock. The camera follows Ki-taek and, in another great shot, we see him descending the stairs. His life is getting even worse, and he is going even lower in the ground. We 
soon find out that he has gone back to the hidden room in the basement of the house. The Kim family is now doomed.

One interesting point about the party and what follows is that after Ki-taek stabs Mr. Park, the Parks vanish from the film, but we continue to see the Kims, especially the son who undergoes a brain surgery. The disappearance of the Park family seems to be significant in a sense that although they no longer live in the house, Ki-taek cannot leave the basement, because the house is on sale now, and another wealthy family (other members of the same class) will soon move in. It implies that even though a part of the upper class is forcefully removed from his place, there is always another family of the same kind to take over, thereby maintaining the social order. The Kims, on the other hand, are doomed to be the underdogs, live in the shadows, and lead a life far worse than before. The removal (death) of the father of the Park family does not result in the emancipation of the father of the other. Thus viewed, Parasite can be interpreted as a bleak picture of capitalist societies in which the poor can never shake off their misery, as life will always be the same for them as it will be for the rich. In the closing section of the movie, we learn about the content of the son's letter to his father, who is hiding in the basement. The son writes that he is going to study, become rich, buy the house, and ultimately save his father, and we see it happening 
as imagined by the son. We know that it is only a dream and it will never be materialized and the father will continue to live in the basements - indefinitely.

\section{Conclusion}

The paper aimed to examine how Bong Joon-ho's Parasite becomes an extended metaphor for class stratification in contemporary South Korea, and the world, and how it emphasizes the existence of clear borderlines between the rich and the poor, and the inability of the latter to exercise social mobility in an industrial and capitalistic world. Through a complex story of two completely different families whose fate gets intermingled, Bong Joon-ho masterfully gives a metaphoric picture of a society where inequality is rampant and the poor can only achieve temporary happiness in the shadow of the rich. The article reveals that the pejorative title word of the movie specifically refers to the Kim family who starts off with high hopes of progress, but ends up losing everything. Such metaphors as the smell, insect, the rock, the head to head clash of the classes in the party, and the basement house (which eventually shifts into a cell for the father) all suggest that families like the Kims are no better than parasites, no matter how intelligent or hardworking they are. In this respect, the movie can be taken as a critique of capitalism and the capitalist society. It implies that the word parasite may as well refer to the Park family who leeches off the poor, as dispensable and easily replaceable hosts. As mentioned earlier, Boon Joon-ho has 
always tackled social and political issues in his films, and Parasite follows the same path, only this time, there is an underlying pessimism in his treatment of the poor and the lowly. Similar to his earlier films, Parasite also enjoys a genre play where the first act of the film has various comical features, while the rest of the film becomes bleak, somber, and tragic. Once again, Bong Joon-ho "appropriates and reworks genre conventions, using them as a framework for exploring and criticizing South Korean social and political issues. Bong reconfigures Hollywood's conventions so that they become tools for grappling with Korean questions" (Klein 2008, 873), and with Parasite, he has successfully managed to show us a glimpse of class conflict in South Korea while hinting at a need for a global change to rework the system or, at least, fill the gap between the social classes.

\section{Bibliography}

Ankers, A. (2020). "Parasite: Bong Joon-ho Reveals the Meaning Behind the Title of the OscarNominated Film.” IGN, January 31. Accessed May 2, 2020. https://www.ign.com/articles/parasitebong-joon-ho-reveals-the-meaning-behind-the-title-of-the-oscar-nominated-film.

Gandal, K. (2007). Class Representation in Modern Fiction and Film. London: Palgrave Macmillan.

James, D. (1999). Is There Class in This Text?: The Repression of Class in Film and Cultural Studies. In T. Miller and R. Stam Eds. A Companion to Film Theory. Blackwell, (pp. 182-201). 
Joon-ho, B. (2019a). "Bong Joon-ho on Weaving His Personal Memories into Parasite". (Karen Han, Interviewer). Polygon, October 14. Accessed May 2, 2020. https://www.polygon.com/ 2019/10/14/20906430/ parasite-bong-joon-ho-interview-rock-peach-spoilers.

Joon-ho, B. (2019b). “Parasite: International Press Kit.” 2019. Accessed May 2, 2020. https://cdnmedia.festivalcannes.com/film_film/0001/66/72f026493fedd9576b0ebc4b7837fd67b8cc95a3.pdf.

Kapur, J., \& Wagner, K. B. (Eds.). (2011). Neoliberalism and global cinema: capital, culture, and Marxist critique. Routledge.

Klein, C. (2008). Why American Studies Needs to Think about Korean Cinema, or, Transnational Genres in the Films of Bong Joon-ho. American Quarterly, 60(4): 871-898. https://doi.org/10.1353/aq.0.0041.

Kleinhans, C., \& Lesage, J. (1977). Marxism and film criticism: The current situation. Minnesota Review, 8(1), 146-149.

La Force, T. (2019). “Why Does Rage Define 'Parasite' and Other Popular East Asian Movies?" The New York Times, November 25. Accessed May 2, 2020. https://www.nytimes.com/2019/11/25/t-magazine/asia-movies-parasite.html.

Lee, F., and S. Manicastri. 2018 "Not All are Aboard: Decolonizing Exodus in Joon-ho Bong's Snowpiercer." New Political Science, 40 no. 2: 211-226, https://doi.org/10.1080/07393148.2018.1449405.

Marx, K. (1972). The Eighteenth Brumaire of Louis Bonaparte. Moscow: Progress Publishers.

Marx, K. (1976). Capital Volume 1. London: Penguin Classics.

Parasite. 2019. Directed by Bong Joon-Ho. Barunson E\&A. Blurray.

Pehlivan, B. M., \& Atalay, G. E. (2017). Aestheticizing the Downfall of Industrial Capitalism: Jim Jarmusch's Tale of Intellectual Vampires in Zombies' World. CINEJ Cinema Journal, 6(2), 3248. 
Scase, R. (1992). Class. Buckingham: Open University Press.

Schulze, J. (2018) Pig in the City: The Authentic Local vs Corporate Cartoons in Bong Joon-ho's Okja. Alternate Takes, April 14. Accessed May 2, 2020. http://www.alternatetakes.co.uk/?2018,4,674

Turner, G. (1999). Film as Social Practice. London: Routledge.

Weber, M. (1978). The Distribution of Power Within the Political Community: Class, Status, Party. In G. Roth and C. Wittich, Eds. Economy and Society: An Outline of Interpretive Sociology, University of California Press, (pp. 926-40). 